\title{
On the apparent $\mathrm{CO}_{2}$ absorption by alkaline soils
}

\section{Chen ${ }^{1}$ and W. F. Wang ${ }^{1,2}$}

${ }^{1}$ State Key Laboratory of Desert and Oasis Ecology, Xinjiang Institute of Ecology and Geography, Chinese Academy of Sciences, Urumqi, Xinjiang, China

${ }^{2}$ University of Chinese Academy of Sciences, Beijing, China

Received: 25 January 2014 - Accepted: 3 February 2014 - Published: 14 February 2014

Correspondence to: X. Chen (chenxi@ms.xjb.ac.cn)

Published by Copernicus Publications on behalf of the European Geosciences Union.

On the apparent $\mathrm{CO}_{2}$ absorption by

alkaline soils

X. Chen and W. F. Wang

Title Page

Abstract

Introduction

Conclusions

References

Tables

Figures

14 >I

4

Back

Close

Full Screen / Esc

Printer-friendly Version

Interactive Discussion 


\section{Abstract}

Alkaline soils in the Gubantonggut Desert were recently demonstrated socking away large quantities of $\mathrm{CO}_{2}$ in an abiotic form. This demands a better understanding of abiotic $\mathrm{CO}_{2}$ exchange in alkaline sites. Reaction of $\mathrm{CO}_{2}$ with the moisture or dew in 5 the soil was conjectured as a potential mechanism. The main goal of this study is to determine the extent to which the dew deposition modulates Land-Atmosphere $\mathrm{CO}_{2}$ exchange at highly alkaline sites $(\mathrm{pH} \sim 10)$. Experiments were conducted at the most barren sites (canopy coverage $<5 \%$ ) to cut down uncertainty. Dew quantities and soil $\mathrm{CO}_{2}$ fluxes were measured using a micro-lysimeters and an automated flux system

10 (LI-COR, Lincoln, Nebraska, USA), respectively. There is an evident increase of dew deposition in nocturnal colder temperatures and decrease in diurnal warmer temperatures. Variations of soil $\mathrm{CO}_{2}$ flux are almost contrary, but the increase in diurnal warmer temperatures is obscure. It was shown that the accumulation and evaporation of dew in the soil motivates the apparent absorption and release of $\mathrm{CO}_{2}$. It was demonstrated 15 that dew amounts in the soil has an exponential relation with the part in $F_{\mathrm{c}}$ beyond explanations of the worldwide utilized $Q_{10}$ model. Therefore dew deposition in highly alkaline soils exerted a potential $\mathrm{CO}_{2}$ sink and can partly explain the apparent $\mathrm{CO}_{2}$ absorption. This implied a crucial component in the net ecosystem carbon balance (NECB) at alkaline sites which occupies approximately $5 \%$ of the Earth's land surface (7 million $\mathrm{km}$ ). Further explorations for its mechanisms and representativeness over other arid climate systems have comprehensive perspectives in the quaternary research.

\section{Introduction}

After the Industrial Revolution, the world's concerned scientific community made a huge effort to investigate sources and sinks in the global carbon cycle, which revealed that the global $\mathrm{CO}_{2}$ budget cannot be balanced unless invoking a missing sink (Detwiler
BGD

11, 2665-2683, 2014

On the apparent $\mathrm{CO}_{2}$ absorption by alkaline soils

X. Chen and W. F. Wang

Title Page

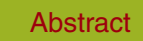

Introduction

Conclusions

References

Tables

Figures

14

$\rightarrow 1$

4

Back

Close

Full Screen / Esc

Printer-friendly Version

Interactive Discussion 
et al., 1988; Tans et al., 1990). Soil $\mathrm{CO}_{2}$ flux $\left(F_{\mathrm{c}}\right)$ accounts for 20-38\% of the annual, global terrestrial and marine $\mathrm{CO}_{2}$ emissions into the atmosphere and is a crucial modulator for ongoing anthropogenic perturbations to the natural carbon cycle (Raich et al., 1992). In most publications, $F_{\mathrm{c}}$ was primarily attributed to the root and microbial respi5 ratory components (Billings et al., 1998; Holt et al., 1990; Reth et al., 2005). However, soil abiotic $\mathrm{CO}_{2}$ exchange was recently recommended to explain some mysterious $\mathrm{CO}_{2}$ fluxes measured over the carbonate ecosystems (Emmerich, 2003; Fang et al., 2001; Kowalski et al., 2008). Although further investigations are still required to determine whether these mysterious $\mathrm{CO}_{2}$ fluxes are "anomalous" or representative (Schlesinger 10 et al., 2009), they can temporally dominate the net ecosystem carbon balance (NECB) (Serrano-Ortiz et al., 2010; Sanchez-Cañete et al., 2011; Kowalski et al., 2008; Inglima et al., 2009) and implies a hidden carbon cycle loop potentially contributing to the longsought missing sink (Stone, 2008).

Especially, the measurements of $F_{\mathrm{c}}$ in the Gubantonggut Desert demonstrated that 15 alkaline soils are socking away large quantities of $\mathrm{CO}_{2}$ in an abiotic form (Stone, 2008; Xie et al., 2009). This demands a better understanding of abiotic $\mathrm{CO}_{2}$ exchange in alkaline soils. Further studies demonstrated that the soil abiotic $\mathrm{CO}_{2}$ exchange has a significant implication to the diel pattern of $F_{c}$ (Chen et al., 2013). Despite of its littleknown soil mechanism, it has been further demonstrated by measurements at alkaline sites over other arid regions and ecosystems (Yates et al., 2013), implying that the extent to which alkaline soil modulates carbon dynamics on regional and global scales was inadequately studied and poorly understood. Alkaline soils occupy approximately $5 \%$ of the Earth's land surface ( 7 million $\mathrm{km}$ ), and will increase due to the global trend towards increasing desertification (Xie et al., 2009). So it is significant to identify the determining environmental factors of $F_{\mathrm{c}}$ in alkaline soils and address its response to the simultaneously varying physical and biotic factors (Ball et al., 2009).

In speculation from soil chemists, reaction of $\mathrm{CO}_{2}$ with the moisture or dew in the soil was recommended as a potential mechanism (Stone et al., 2008). This scenario is plausible. It might explain the story for apparent $\mathrm{CO}_{2}$ absorption by alkaline soils at
BGD

$11,2665-2683,2014$

On the apparent $\mathrm{CO}_{2}$ absorption by alkaline soils

X. Chen and W. F. Wang

Title Page
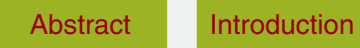

Conclusions

Tables

References

Figures

14

$\rightarrow 1$

4

Back

Close

Printer-friendly Version

Interactive Discussion 
summer night, when $\mathrm{CO}_{2}$ can react with moisture in the soil and perhaps with dew to form carbonic acid, which in turn dissolves calcium carbonate (unlike most minerals, carbonates become more soluble at lower temperatures). It must be noted that diurnal warmer temperatures would drive a reverse reaction and release the $\mathrm{CO}_{2}$ again dur5 ing the night. It is still undetermined whether the accumulation of dew in the soil can motivate the apparent absorption of $\mathrm{CO}_{2}$. To make things worse, the dew deposition in alkaline soils would vary from season to season, implying no significant increase in soil storage due to this process over a year.

Nevertheless, the conjecture is intriguing and must be followed up. In arid and semi10 in providing an essential source of water for alkaline soils. Especially in desert ecosystems, the water resources are severely limited and dewfall and early morning evaporation are the most important processes affecting the daily water balance of the upper soil layer (Ball et al., 2009; Broza, 1979; Duvdevani, 1964; Jacobs et al., 1999; Moffett, Gubantonggut Desert has been demonstrated (Zhang et al., 2009; Liu et al., 2012). Even if the reaction of $\mathrm{CO}_{2}$ with the moisture or dew in alkaline soils were negligible, the significant dew deposition might exert a potential $\mathrm{CO}_{2}$ sink and partly explain apparent $\mathrm{CO}_{2}$ absorption frequently occurs in nighttime flux measurements (Xie et al., 2009; Yates et al., 2013).

The objectives of this research are to present the details in the variations of $F_{\mathrm{c}}$ with dew accumulation and evaporation in alkaline soils, and in turn, to achieve a better understanding of the relationship between dew deposition and apparent $\mathrm{CO}_{2}$ absorption in alkaline soils. Diel variations of dew amounts with air temperature at $10 \mathrm{~cm}$ above the soil surface were determined. Measurements of $F_{\mathrm{c}}$ at highly alkaline sites $(\mathrm{pH} \sim 10)$ were conducted along a gradient of dew amounts. This might present a better understanding of the extent to which dew deposition modulates the Land-Atmosphere $\mathrm{CO}_{2}$ exchange at highly alkaline sites and the possible implications to the net ecosystem carbon balance (NECB).
BGD

$11,2665-2683,2014$

On the apparent $\mathrm{CO}_{2}$ absorption by alkaline soils

X. Chen and W. F. Wang

Title Page

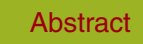

Introduction

Conclusions

Tables

References

Figures

14

$\rightarrow$

4

Back

Close

Full Screen / Esc

Printer-friendly Version

Interactive Discussion 


\section{Materials and methods}

I claim that all the experiments in the study were conducted at the Gubantonggut Desert. I confirmed that no specific permissions were required for this research, and exactly, the local government encouraged us to do so since it improved the environ5 ment. No endangered or protected species were involved in the field studies.

\subsection{Site description}

The considered highly alkaline sites are from an arid climate system in the southern periphery at the Gubantonggut Desert, which is located at the hinterland of the Eurasian Continent. Soils are clay-loam of a texture with heavy alkalinity. Because of extremely 10 arid meteorological conditions (annual sunshine hour: $3079 \mathrm{~h}$; annual precipitation: $144.7 \mathrm{~mm}$; annual evapotranspiration: $2020 \mathrm{~mm}$; annual Rad intensity: $5439 \mathrm{MJm}^{-2}$; annual mean wind velocity: $2.6 \mathrm{~ms}^{-1}$ ), dew deposition is an essential source of water and the nighttime vapor uptake by alkaline soils is evident during the arid growing seasons (Zhang et al., 2009). To highlight the role of the abiotic components in $F_{\mathrm{c}}$, the most barren sites (canopy coverage $<5 \%$ ) were chosen for our case study. There is no significant difference in the geochemical properties between sites. To cut down uncertainty, only bare, highly alkaline sites $(\mathrm{pH} \sim 10)$ far from the sparse vegetation were considered. All the experiments in the study were conducted at the Gubantonggut Desert. No specific permissions were required for this research, and exactly, the local 20 government encouraged us to do so since it improved the environment. No endangered or protected species were involved in the field studies.

\subsection{Soil $\mathrm{CO}_{2}$ flux measurements}

Measurements of $F_{\mathrm{c}}$ were conducted during an arid growing season of 2006, using an LI-8100 Automated Soil CO 2 Flux System (LI-COR, Lincoln, Nebraska, USA), equipped with a long-term monitoring chamber (LI-8100L). Before experiments, litter on the soil
On the apparent $\mathrm{CO}_{2}$ absorption by alkaline soils

X. Chen and W. F. Wang

Title Page

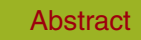

Introduction

Conclusions

References

Tables

Figures

14

$\rightarrow$

4

Back

Close

Full Screen / Esc

Printer-friendly Version

Interactive Discussion 
surface was cleared. In order to minimize the disturbing effect on the soil, at least $48 \mathrm{~h}$ before measurements of $F_{\mathrm{c}}$, steel collars (ca. $20.3 \mathrm{~cm}$ in diameter and $19.5 \mathrm{~cm}$ in depth) were inserted into the soil, with a $5 \mathrm{~cm}$ exposed above the surface for installing the monitoring chamber. Each measurement was commenced at 06:00 and ended at 5 06:00 LT on the next day. During measuring period, $F_{\mathrm{c}}$ value was documented for every $15 \mathrm{~min}$ and each measurement length was $2 \mathrm{~min}$. Air temperature $10 \mathrm{~cm}$ above the surface $\left(T_{\text {as }}\right)$ and relative humidity $(\mathrm{RH})$ were monitored automatically by the corresponding probes equipped with LI-8100 System. To exclude the influence of rainfall, all the observations were conducted in clear days and the collars were covered when 10 raining.

\subsection{Dew quantities measurements}

Measurements of dewfall and evaporation were conducted in growing seasons of 2008, using micro-lysimeters (ca. $6 \mathrm{~cm}$ in diameter and $3.5 \mathrm{~cm}$ in depth), which allows repeated use of the same sample since a soil core can be taken while leaving the sur15 face intact (Boast et al., 1982). The micro-lysimeters were pushed into the ground to collect undisturbed soil columns for control with the edges close to the flat surface of the ground and the bases covered. There were 12 plots $(1 \mathrm{~m} \times 1 \mathrm{~m})$ were taken from each plot at every time. Soil samples were weighted using a balance to a precision of $\pm 0.01 \mathrm{~g}$. Dew amounts was determined by calculating the weight difference. The 20 weighing intervals are $2 \mathrm{~h}$ and $30 \mathrm{~min}$ for the time course of the dew deposition and dew duration respectively. A hygrothermograph $(\mathrm{HC}-520)$ is employed to measure $T_{\text {as }}$ and $\mathrm{RH}$ synchronously.

\subsection{Procedure for sensitivity analysis}

Motivated by the speculation from soil chemists (Stone, 2008), a preliminary analysis were executed to investigate whether the temporal variations of $F_{\mathrm{c}}$ are similar to that of dew amounts in the soil. Following preparation from November 2010 to March 2011
BGD

$11,2665-2683,2014$

On the apparent $\mathrm{CO}_{2}$ absorption by alkaline soils

X. Chen and W. F. Wang

Title Page

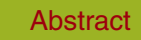

Introduction

Conclusions

References

Tables

Figures

14

$\rightarrow$

4

Back

Close

Full Screen / Esc

Printer-friendly Version

Interactive Discussion 
(a long-term incubation of roots-excluded soils in dry environments to depress the respiratory components in the soil and focus on the implications of dew amounts to soil abiotic $\mathrm{CO}_{2}$ exchange), the further laboratory studies were commenced in August 2012 to observe the variations of $F_{\mathrm{c}}$ with the evaporation and accumulation of dew. An ulti5 mate analysis was conducted to investigate the extent to which dew deposition modulator the part in $F_{\mathrm{c}}$ beyond explanations of the worldwide utilized $Q_{10}$ model (Lloyd et al., 1994), using a developed $Q_{10}$ model as

$$
F_{\mathrm{c}}=R_{10} Q_{10}^{(T-10) / 10}+F_{X}
$$

where $F_{X}$ is the part in $F_{\mathrm{c}}$ beyond explanations of the $Q_{10}$ model, $T=T_{\text {as }}, R_{10}$ is the referred $F_{\mathrm{c}}$ at $10^{\circ}$ and $Q_{10}$ is the factor by which $F_{\mathrm{c}}$ is multiplied when $T$ increases by $10^{\circ}$.

For the model parameterization, first we determined $R_{10}, Q_{10}$ by taking $F_{X}$ as a constant parameter, and then calculated $F_{x}$ by $F_{x}=F_{\mathrm{c}}-R_{10} Q_{10}^{(T-10) / 10}$. The sensitivity of $F_{\mathrm{c}}$ 15 to dew deposition was analyzed by an exponential model as

$F_{x}=a e^{\lambda \mathrm{dew}}+b$

\section{Results}

\subsection{Variations of dew amounts and soil $\mathrm{CO}_{2}$ flux}

20 The dew amounts in four sampled soils indicated no significant spatial difference of dew accumulation and evaporation at highly alkaline sites (Fig. 1). The magnitude of dew amounts in the soil varied largely with a range between some $-0.02 \sim 0.08 \mathrm{~mm}$. Dew accumulations in the measuring period were begun at 20:00 and ended at 08:00 LT on the next day, while dew evaporations were begun at 09:00 and ended at 19:00 LT. Negative dew values implied that dew evaporations in the whole diel cycle were stronger than dew depositions because of the arid climate. There is an evident increase of dew
$11,2665-2683,2014$

On the apparent $\mathrm{CO}_{2}$ absorption by alkaline soils

X. Chen and W. F. Wang

Title Page

Abstract Introduction

Conclusions References

Tables Figures

14 $\rightarrow 1$

4

Back

Close

Full Screen / Esc

Printer-friendly Version

Interactive Discussion 
deposition in nocturnal colder temperatures and evident decrease in diurnal warmer temperatures. Dew amounts, nocturnal colder temperatures, and profile storage of soil inorganic carbon (Wang et al., 2010) implies the possible nighttime accumulations of pedogenic inorganic carbon (PIC) with dew deposition at the considered alkaline sites, 5 which are controlled by the carbonate-bicarbonate equilibria (Eqs. 3 and 4) (Emmerich, 2003):

$\mathrm{CO}_{2}+\mathrm{H}_{2} \mathrm{O} \leftrightharpoons \mathrm{HCO}_{3}^{-}+\mathrm{H}^{+}$

$\mathrm{CaCO}_{3}+\mathrm{H}^{+} \leftrightharpoons \mathrm{Ca}^{2+}+\mathrm{HCO}_{3}^{-}$

10 On the clear days within a growing season of 2006, variations of $F_{\mathrm{c}}$ are almost contrary to those of dew amounts, but the increase in diurnal warmer temperatures became obscure, implying reduced temperature sensitivity of diurnal $\mathrm{CO}_{2}$ fluxes (Fig. 2). This might be attributed to the undetermined but significant time lag between the "apparent" respiration $\left(F_{\mathrm{c}}\right)$ and real respiration $\left(R_{\mathrm{s}}\right)$ (Fang et al., 1999). The intensity of $F_{\mathrm{c}}$ varied

15 largely with a range between some $-1.2 \sim 1.2 \mu \mathrm{molm}^{-2} \mathrm{~s}^{-1}$. Nocturnal negative values of $F_{\mathrm{c}}$ indicated an evident apparent absorption of $\mathrm{CO}_{2}$ in highly alkaline soils, which could be partly attributed to the above well-known chemical reactions.

\subsection{Sensitivity of $F_{\mathrm{c}}$ to dew deposition}

Laboratory temperature-controlled experiments revealed that intensity of $F_{\mathrm{c}}$ definitely decreases with dew accumulation to the soil at colder air temperatures (Fig. 3), with the intensity of $F_{\mathrm{c}}$ varied largely with a range between some $-2 \sim 0.7 \mu \mathrm{molm}^{-2} \mathrm{~s}^{-1}$. About $85 \%$ of measured $F_{\mathrm{c}}$ were negative and indicated apparent $\mathrm{CO}_{2}$ absorption. But dew evaporation from the soil at warmer air temperatures drives $F_{\mathrm{c}}$ in the opposite direction (Fig. 4), where the intensity of $F_{\mathrm{c}}$ varied from $-1 \mu \mathrm{molm} \mathrm{m}^{-2} \mathrm{~s}^{-1}$ to $2.5 \mu \mathrm{molm} \mathrm{m}^{-2} \mathrm{~s}^{-1}$.

About $78 \%$ of measured $F_{\mathrm{c}}$ were positive and indicated apparent $\mathrm{CO}_{2}$ release. Therefore the dew accumulation and evaporation in the soil are closely related to the apparent $\mathrm{CO}_{2}$ absorption (negative $F_{\mathrm{c}}$ ) and the apparent $\mathrm{CO}_{2}$ release (positive $F_{\mathrm{c}}$ ).

2672
BGD

$11,2665-2683,2014$

On the apparent $\mathrm{CO}_{2}$ absorption by alkaline soils

X. Chen and W. F. Wang

Title Page

Abstract Introduction

Conclusions References

Tables Figures

14 $\rightarrow 1$

4

Back

Close

Full Screen / Esc

Printer-friendly Version

Interactive Discussion 
Estimations of $F_{\mathrm{c}}$ with Eq. (1) along a field temperature gradient were still robust and it explains more than $86 \%$ of the data (Fig. $3: R^{2}=0.8630$, RMSE $=0.2334$ ), although $F_{\mathrm{c}}$ varied with a wide range $\left(-1.2 \sim 3.6 \mu \mathrm{molm}^{-2} \mathrm{~s}^{-1}\right)$. Determined $R_{10}, Q_{10}$ (taking $F_{x}$ as a constant $c$ ) shown that high alkalinity significantly affected soil microbial activity 5 and the rate of soil $\mathrm{C}$ cycling $\left(R_{10}>2.5\right)$ and reduced the temperature sensitivity $\left(Q_{10}<\right.$ 1.2). Field estimations of $F_{\mathrm{c}}$ with Eq. (1) also revealed a non-negligible $\mathrm{CO}_{2}$ sink $(c=$ $-2.86)$.

The calculated $F_{X}$ in the soil with negligible dew amounts $(<0.05 \mathrm{~mm})$ varied from $-1.5 \mu \mathrm{mol} \mathrm{m}^{-2} \mathrm{~s}^{-1}$ and $0.1 \mu \mathrm{molm} \mathrm{m}^{-2} \mathrm{~s}^{-1}$, while the calculated $F_{x}$ with significant dew de10 position $\left(>0.05 \mathrm{~mm}\right.$ ) varied largely with a range between some $-7 \sim-1 \mu \mathrm{molm} \mathrm{m}^{-2} \mathrm{~s}^{-1}$. There is an evident decrease of $F_{X}$ with increasing dew amounts. The robustness in the analysis of $F_{X}$ with Eq. (2) was also influenced by dew amounts. It was not robust for negligible dew amounts $\left(\mathrm{b}: R^{2}=0.1008, \mathrm{RMSE}=0.4219\right)$. But it was robust otherwise (c: $R^{2}=0.5264$, $\mathrm{RMSE}=0.7533$ ).

15 It was demonstrated that dew amounts in the soil has an exponential relation with the part in $F_{\mathrm{c}}$ beyond explanations of the worldwide utilized $Q_{10}$ model. Coupled with the relevance between the dew accumulation/evaporation in the soil and the apparent $\mathrm{CO}_{2}$ absorption/release, we concluded that dew deposition in highly alkaline soils exerted a potential $\mathrm{CO}_{2}$ sink and can partly explain the apparent $\mathrm{CO}_{2}$ absorption.

\subsection{Implications and Outstanding issues}

There are numerous studies concerned the behavior of $\mathrm{CO}_{2}$ fluxes over high-carbonate soils implying possible abiotic $\mathrm{CO}_{2}$ exchange in desert ecosystems. Acid rain events were associated with apparent $\mathrm{CO}_{2}$ absorption due to carbonate dissolution (Emmerich, 2003; Kowalski, 2008). And later, when the soil profile dried, the loss of water from the soil solution caused $\mathrm{CO}_{2}$ release (Emmerich, 2003). Other concordant studies also concluded that an abiotic $\mathrm{CO}_{2}$ source (dissolution of carbonates) provoke a portion of the measured $\mathrm{CO}_{2}$ emissions (Wohlfahrt et al., 2008). Abiotic exchange can
BGD

$11,2665-2683,2014$

On the apparent $\mathrm{CO}_{2}$ absorption by alkaline soils

X. Chen and W. F. Wang

Title Page

Abstract Introduction

Conclusions

Tables References Figures

14 $\rightarrow 1$

4

Back

Close

Printer-friendly Version

Interactive Discussion 
temporally dominate the net $\mathrm{CO}_{2}$ exchanges of carbonate soils with the atmosphere, according to the large $\mathrm{CO}_{2}$ release during the dry seasons in two carbonate ecosystems and weathering processes (dissolution and precipitation of carbonates) were suggested interpreting anomalous $\mathrm{CO}_{2}$ fluxes over carbonate ecosystems (Kowalski et al., 5 2008).

Although the true mechanisms are still in debate (Schlesinger et al., 2009), soil abiotic $\mathrm{CO}_{2}$ exchange may be significant in the global carbon cycle and could even represent the long-sought missing carbon sink (Stone, 2008). High contributions of soil inorganic carbon release ( $40 \%$ of the total soil $\mathrm{CO}_{2}$ efflux) during dry soil condi10 tions in a carbonate Mediterranean ecosystem have been demonstrated (Inglima et al., 2009). Large magnitudes of $\mathrm{CO}_{2}$ uptake were observed from soil chambers in the Gubantonggut Desert and highlighted that deserts are unsung players in the carbon cycle (Stone, 2008; Xie et al., 2009). Estimated NECB for a Mojave Desert grassland ecosystem exceeds $100 \mathrm{~g} \mathrm{~m}^{-2} \mathrm{yr}^{-1}$, which are similar to that of some temperate forests

(Wohlfahrt et al., 2008). It was originally attributed to the expansion and growth of cryptobiotic crust organisms (Wohlfahrt et al., 2008), but other scientists pointed out that these crust species are neither sufficiently active nor extensive to explain such a magnitude of $\mathrm{CO}_{2}$ uptake (Stone, 2008). Certainly, the large $\mathrm{CO}_{2}$ uptake is also beyond of explanation by weathering processes and subterranean cavities as a temporal depot of $\mathrm{CO}_{2}$, along with their seasonal ventilation were hypothesized as further abiotic mechanisms (Serrano-Ortiz et al., 2010).

The present study suggested that dew amounts was a crucial modulator for the Land-Atmosphere $\mathrm{CO}_{2}$ exchange in highly alkaline soils $(\mathrm{pH} \sim 10)$ at the most barren sites (canopy coverage $<5 \%$ ). Accumulation and evaporation of dew in the soil were demonstrated to be a sensitive modulator for the apparent $\mathrm{CO}_{2}$ absorption and release at desert alkaline soils. Interpretations of soil abiotic $\mathrm{CO}_{2}$ exchange observed over the considered desert system might be not too easy for quite understanding. But profile storage of soil inorganic carbon revealed high carbonate content of alkaline soils at the same desert (Wang et al., 2010) and soil $\mathrm{CO}_{2}$ flux measurements demonstrated
BGD

$11,2665-2683,2014$

On the apparent $\mathrm{CO}_{2}$ absorption by alkaline soils

X. Chen and W. F. Wang

Title Page



Introduction

Conclusions

Tables

References

Figures

14

- I

4

Back

Close

Full Screen / Esc

Printer-friendly Version

Interactive Discussion 
the significance of abiotic $\mathrm{CO}_{2}$ exchange in typical alkaline sites at this desert (Xie et al., 2009).

Nevertheless, the underlie mechanisms for dew deposition to modulator $\mathrm{CO}_{2}$ flux in highly alkaline soils are complex and undetermined. Moreover, we cannot claim its 5 representativeness over other arid climate systems or even for other alkaline soils $(\mathrm{pH}<10)$ in the considered desert ecosystems. Further explorations are hence required.

\section{Conclusions}

Dew evaporation and accumulation have potential influence on $\mathrm{CO}_{2}$ fluxes in highly

alkaline soil. As an environmental factor that simultaneously varies with temperature, it might be partly responsible for the reduced temperature sensitivity. Dew amounts in the soil have an exponential relation with the part in $F_{\mathrm{c}}$ beyond explanations of the worldwide utilized $Q_{10}$ model. The extent to which the dew deposition modulates LandAtmosphere $\mathrm{CO}_{2}$ exchange in alkaline soils was inadequately studied and poorly un15 derstood. Dew deposition in highly alkaline soils exerts a potential $\mathrm{CO}_{2}$ sink and can partly explain the apparent $\mathrm{CO}_{2}$ absorption. This implied a crucial component in the net ecosystem carbon balance (NECB) at alkaline sites which occupies approximately $5 \%$ of the Earth's land surface ( 7 million $\mathrm{km}$ ) and has comprehensive perspectives in the quaternary research.

Acknowledgements. This research was supported by the National Basic Research Program of China (2009CB 825105). We are grateful to the Xinjiang and Central Asia Scientific Data Sharing Platform for access to data.

On the apparent $\mathrm{CO}_{2}$ absorption by alkaline soils

X. Chen and W. F. Wang

Title Page



Introduction

Conclusions

References

Tables

Figures

14

-1

4

Back

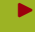

Full Screen / Esc

Printer-friendly Version

Interactive Discussion 


\section{References}

Ball, B. A., Virginia, R. A., Barrett, J. E., Parsons, A. N., and Wall, D. H.: Interactions between physical and biotic factors influence $\mathrm{CO}_{2}$ flux in Antarctic dry valley soils, Soil Biol. Biochem., 41, 1510-1517, 2009.

5 Billings, S. A., Richter, D. D., and Yarie, J.: Soil carbon dioxide fluxes and profile concentrations in two boreal forests, Can. J. Forest Res., 28, 1773-1783, 1998.

Boast, C. W. and Robertson, T. M.: A "micro-lysimeter" method for determining evaporation from bare soil: description and laboratory evaluation, Soil Sci. Soc. Am. J., 46, 689-696, 1982.

10 Broza, M.: Dew, fog and hygroscopic food as a source of water for desert arthropods, J. Arid. Environ., 2, 43-49, 1979.

Chen, X., Wang, W. F., Luo, G. P., Li, L. H., and Li, Y.: Time lag between carbon dioxide influx to and efflux from bare saline-alkali soil detected by the explicit partitioning and reconciling of soil $\mathrm{CO}_{2}$ flux, Stoch. Env. Res. Risk A, 27, 1-9, 2013.

15 Detwiler, R. P. and Hall, C. A. S.: Tropical forests and the global carbon cycle, Science, 239, 42-47, 1988.

Duvdevani, S.: Dew in Israel and its effect on plants, Soil Sci., 2, 14-21, 1964.

Emmerich, E. W.: Carbon dioxide fluxes in a semiarid environment with high carbonate soils, Agr. Forest Meteorol., 116, 91-102, 2003.

20 Fang, J. Y., Tang, Y. H., Koizumi, H., and Bekku, Y.: Evidence of winter time $\mathrm{CO}_{2}$ emission from snow-covered grounds in high latitudes, Sci. China Ser. D, 42, 378-382, 1999.

Fang, J. Y., Piao, S. L., Tang, Z. Y., Peng, C. H., and Ji, W.: Interannual variability in net primary production and precipitation, Science, 293, 1723-1723, 2001.

Holt, J. A., Hodgen, M. J., and Lamb, D.: Soil respiration in the seasonally dry tropics near Townsville, North Queensland, Aust. J. Soil Res., 28, 737-745, 1990.

Inglima, I., Alberti, G., Bertolini, T., Vaccari, F. P., Gioli, B., Miglietta, F., M. F. Cotrufo, and Peressotti, A.: Precipitation pulses enhance respiration of Mediterranean ecosystems: the balance between organic and inorganic components of increased soil $\mathrm{CO}_{2}$ efflux, Glob. Change Biol., 15, 1289-1301, 2009.

30 Jacobs, A. F. G., Heusinkveld, B. G., and Berkowicz, S. M.: Dew deposition and drying in a desert system: a simple simulation model, J. Arid. Environ., 42, 211-222, 1999.

On the apparent $\mathrm{CO}_{2}$ absorption by alkaline soils

X. Chen and W. F. Wang

Title Page

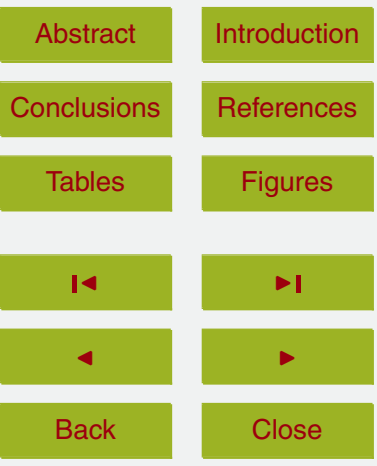

Full Screen / Esc

Printer-friendly Version

Interactive Discussion 
Kowalski, A. S., Serrano-Ortiz, P., Janssens, I. A., Sánchez-Moral, S., Cuezva, S., Domingo, F., Were, A., and Alados-Arboledas, L.: Can flux tower research neglect geochemical $\mathrm{CO}_{2}$ exchange?, Agr. Forest Meteorol., 148, 1045-1054, 2008.

Liu, R., Pan, L. P., Jenerette, G. D., Wang, Q. X., Cieraad, E., and Li, Y.: High efficiency in water use and carbon gain in a wet year for a desert halophyte community, Agr. Forest Meteorol., 162, 127-135, 2012.

Lloyd, J. and Taylor, J. A.: On the temperature dependence of soil respiration, Funct. Ecol., 8, 315-323, 1994.

Mielnick, P., Dugas, W. A., Mitchell, K., and Havstad, K.: Long-term measurements of $\mathrm{CO}_{2}$ flux and evapotranspiration in a Chihuahuan desert grassland, J. Arid. Environ., 60, 423-436, 2005.

Moffett, M. W.: An Indian ant's novel method for obtaining water, Natl. Geogr. Res., 1, 146-149, 1985.

Raich, J. W. and Schlesinger, W. H.: The global carbon dioxide flux in soil respiration and its relationship to vegetation and climate, Tellus B, 44, 81-99, 1992.

Reth, S., Reichstein, M., and Falge, E.: The effect of soil water content, soil temperature, soil $\mathrm{pH}$-value and the root mass on soil $\mathrm{CO}_{2}$ efflux - a modified model, Plant Soil, 268, 21-33, 2005.

Sanchez-Cañete, E. P., Serrano-Ortiz, P., Kowalski, A. S., Oyonarte, C., and Domingo, F.: Subterranean $\mathrm{CO}_{2}$ ventilation and its role in the net ecosystem carbon balance of a karstic shrubland, Geophys. Res. Lett., 38, L09802, doi:10.1029/2011GL047077, 2011.

Schlesinger, W. H., Belnap, J., and Marion, G.: On carbon sequestration in desert ecosystems, Glob. Change Biol., 15, 1488-1490, 2009.

Serrano-Ortiz, P., Roland, M., Sánchez-Moral, S., Janssens, I. A., Domingo, F., Goddéris, Y., and Kowalski, A. S.: Hidden, abiotic $\mathrm{CO}_{2}$ flows and gaseous reservoirs in the terrestrial carbon cycle: review and perspectives, Agr. Forest Meteorol., 150, 321-329, 2010.

Stone, R.: Have desert researchers discovered a hidden loop in the carbon cycle?, Science, 320, 1409-1410, 2008.

Tans, P. P., Fung, Y., and Takahashi, T.: Observational constraints on the global atmospheric $\mathrm{CO}_{2}$ budget, Science, 247, 1431-1438, 1990.

Wang, Y. G., Li, Y., Ye, X. H., Chu, Y., and Wang, X. P.: Profile storage of organic/inorganic carbon in soil: from forest to desert, Sci. Total Environ., 408, 1925-1931, 2010.

On the apparent $\mathrm{CO}_{2}$ absorption by alkaline soils

X. Chen and W. F. Wang

Title Page

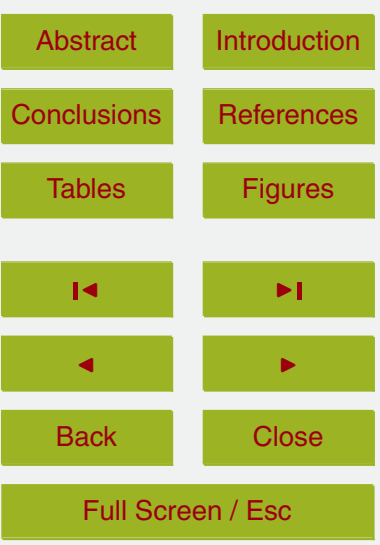

Printer-friendly Version

Interactive Discussion 
Wohlfahrt, G., Fenstermaker, L. F., and Arnone, J. A.: Large annual net ecosystem $\mathrm{CO}_{2}$ uptake of a Mojave Desert ecosystem, Glob. Change Biol., 14, 1475-1487, 2008.

Xie, J. X., Li, Y., Zhai, C. X., Li, C. H., and Lan, Z. D.: $\mathrm{CO}_{2}$ absorption by alkaline soils and its implication to the global carbon cycle, Environ. Geol., 56, 953-961, 2009.

5 Yates, E. L., Detweiler, A. M., Iraci, L. T., Bebout B. M., McKay C. P., Schiro K., Sheffner E. J., Kelley C. A., Tadić, J. M., and Loewenstein, M.: Assessing the role of alkaline soils on the carbon cycle at a playa site, Environ. Earth Sci., 70, 1047-1056, 2013.

Zhang, J., Zhang, Y. M., Downing, A., Cheng, J. H., Zhou, X. B., and Zhang, B. C.: The influence of biological soil crusts on dew deposition in Gurbantunggut Desert, Northwestern China, J. Hydrol., 379, 220-228, 2009.

On the apparent $\mathrm{CO}_{2}$ absorption by alkaline soils

X. Chen and W. F. Wang

Title Page

Abstract Introduction

Conclusions References

Tables Figures

14

4

Back

Close

Full Screen / Esc

Printer-friendly Version

Interactive Discussion 



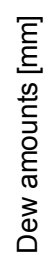

Time of day [hour]

11, 2665-2683, 2014

On the apparent $\mathrm{CO}_{2}$ absorption by alkaline soils

X. Chen and W. F. Wang

Title Page

Abstract

Introduction

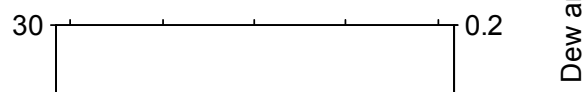

Conclusions

References

Tables

Figures

14

$>$ I

4

Back

Close

\section{Full Screen / Esc}

Printer-friendly Version

Fig. 1. Diurnal and nocturnal variations of dew evaporation and accumulation (•) in four soil samples and the simultaneous variations of air temperature $10 \mathrm{~cm}$ above the soil surface $(+)$. 

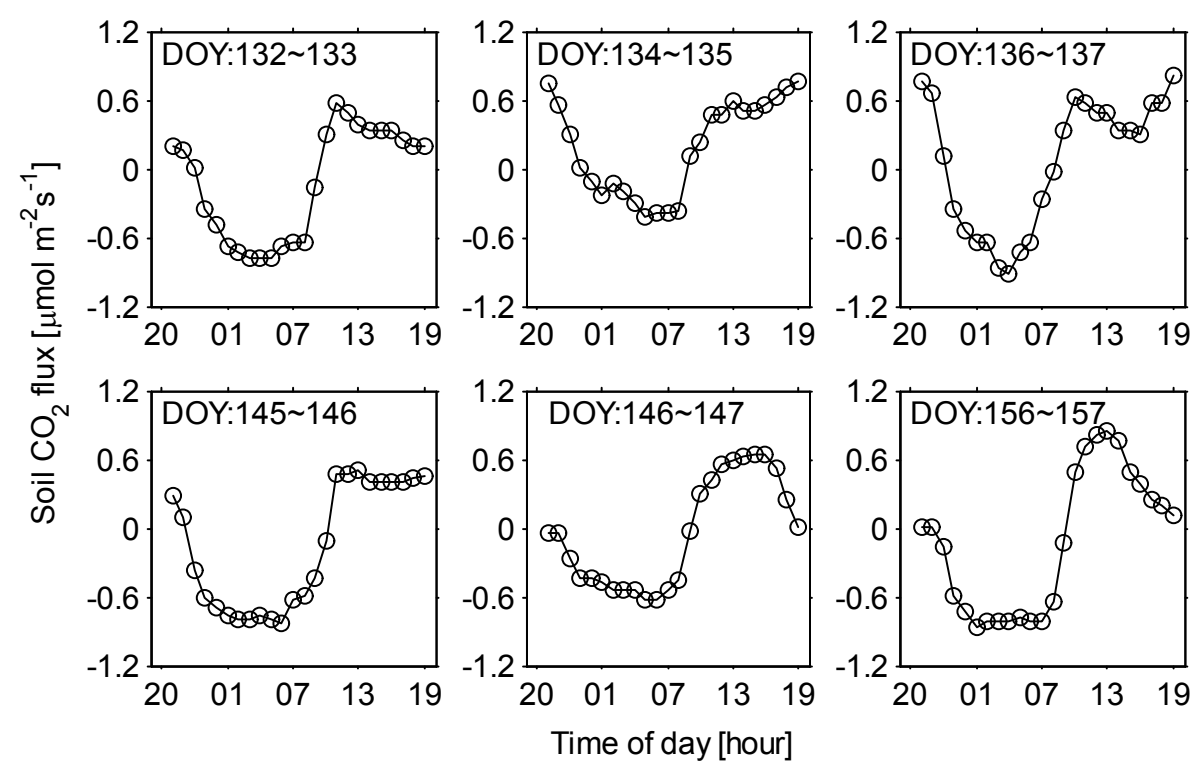

Fig. 2. Diurnal and nocturnal variations of $\mathrm{CO}_{2}$ flux in highly alkaline soils on clear days within a growing season of 2006 .

\section{BGD}

11, 2665-2683, 2014

On the apparent $\mathrm{CO}_{2}$ absorption by alkaline soils

X. Chen and W. F. Wang Title Page

\section{Abstract} Introduction

Conclusions References

Tables Figures

14



Back

Close

Full Screen / Esc

Printer-friendly Version

Interactive Discussion 

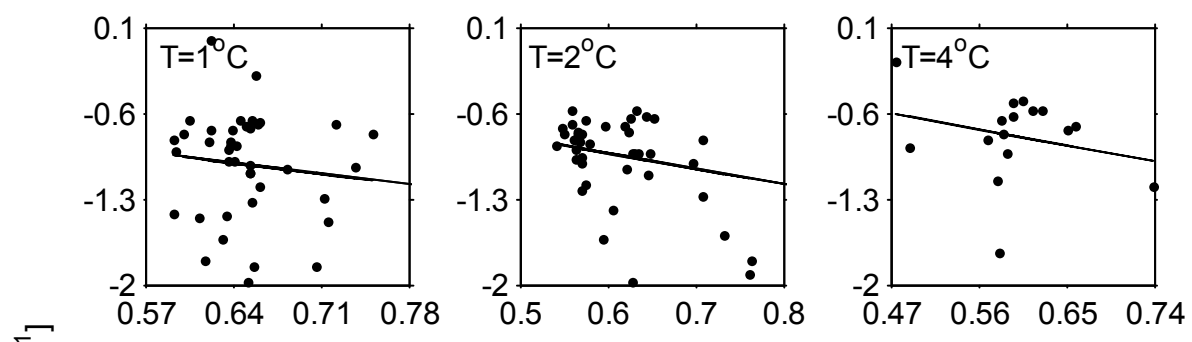

BGD

11, 2665-2683, 2014

On the apparent $\mathrm{CO}_{2}$ absorption by alkaline soils
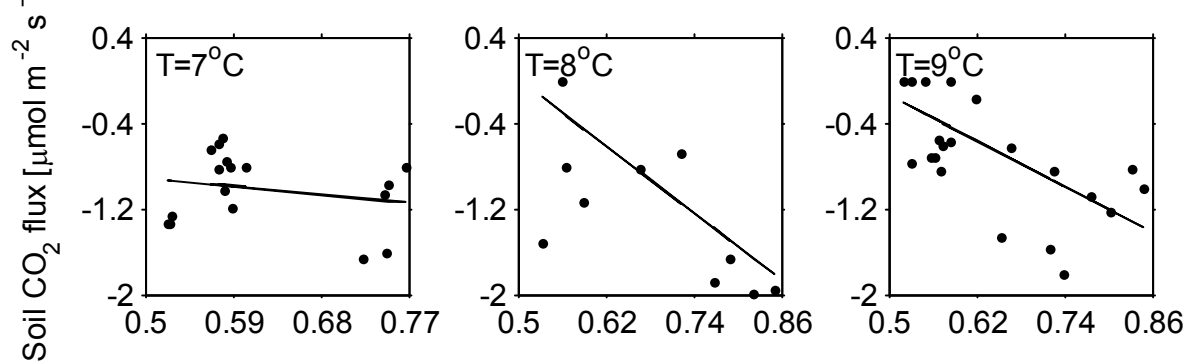

X. Chen and W. F. Wang
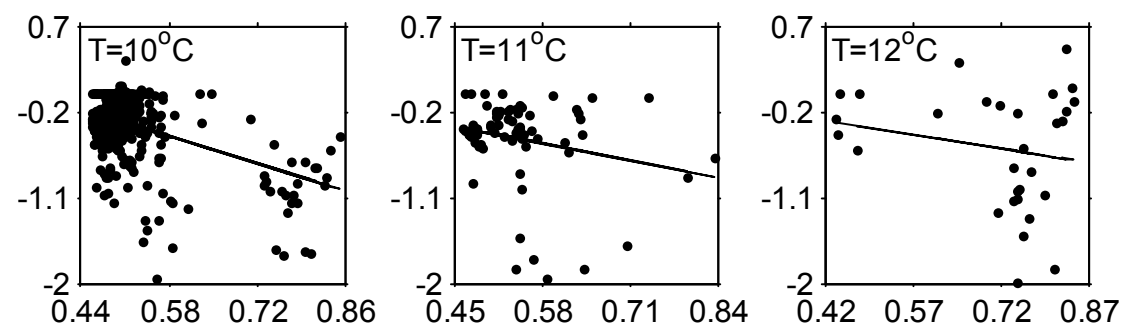

Dew accumulation [mm]

Title Page

Abstract

Introduction

Conclusions

References

Tables

Figures

14

I

4

Back

Close

\section{Full Screen / Esc}

Printer-friendly Version

Fig. 3. Variations of soil $\mathrm{CO}_{2}$ flux with dew accumulation along a laboratory gradient of colder air temperatures $(T)$.

Interactive Discussion 


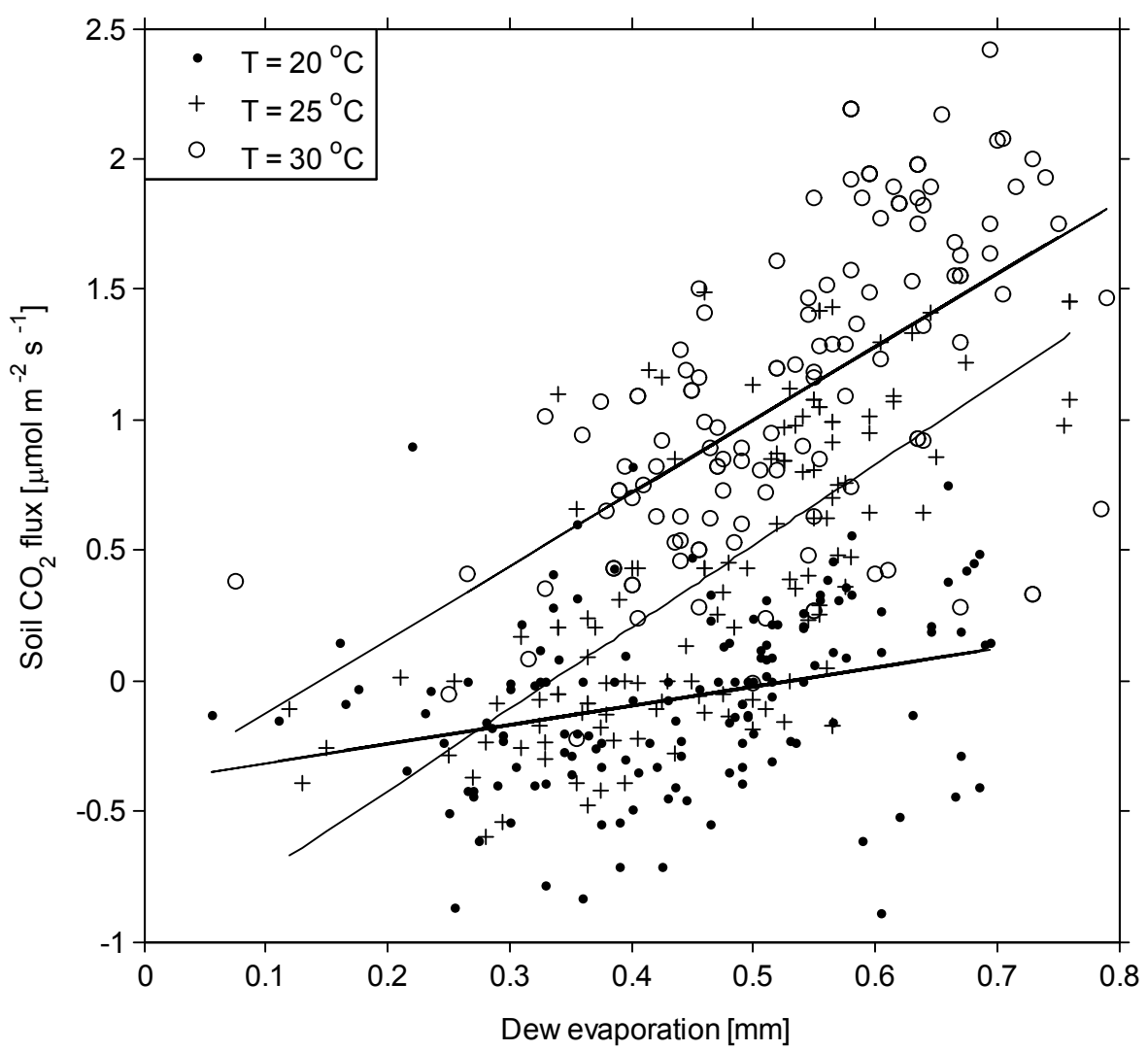

Fig. 4. Variations of soil $\mathrm{CO}_{2}$ flux with dew evaporation along a laboratory gradient of warmer air temperatures $(T)$.
BGD

$11,2665-2683,2014$

On the apparent $\mathrm{CO}_{2}$ absorption by alkaline soils

X. Chen and W. F. Wang

Title Page



Full Screen / Esc

Printer-friendly Version

Interactive Discussion 

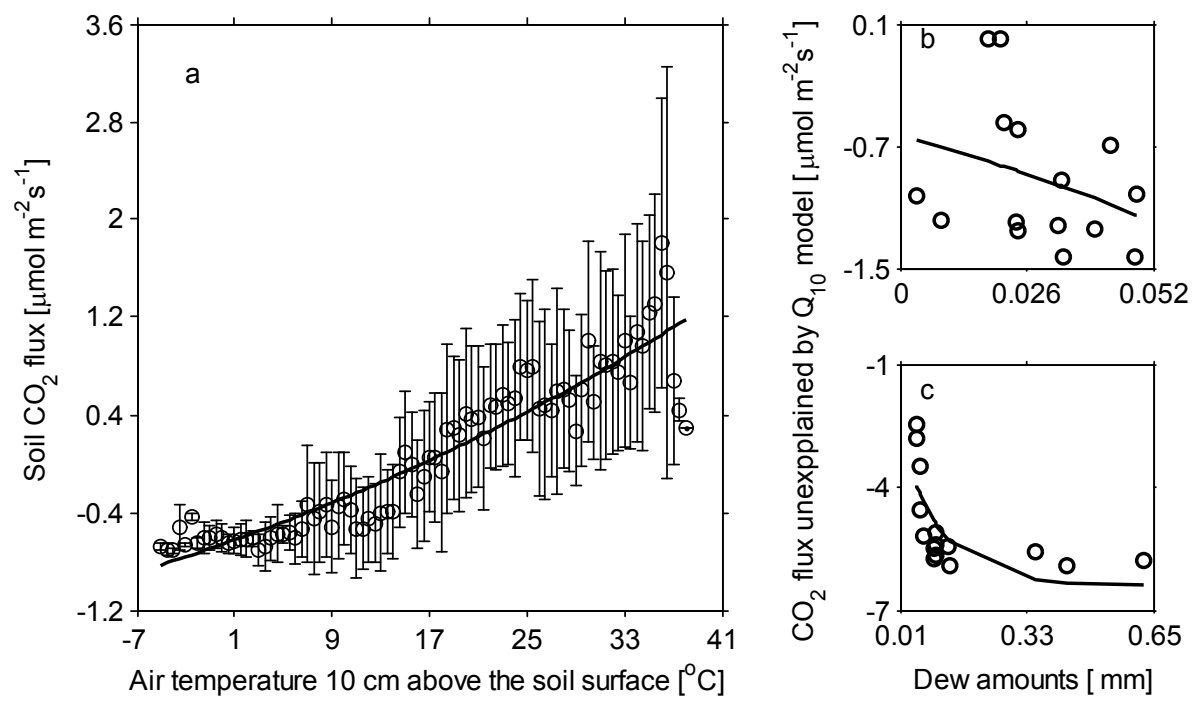

On the apparent $\mathrm{CO}_{2}$ absorption by alkaline soils

X. Chen and W. F. Wang

Title Page

Abstract

Introduction

Conclusions

References

Tables

Figures

14

I

4

Fig. 5. Estimation of soil $\mathrm{CO}_{2}$ flux $\left(F_{\mathrm{c}}\right)$ with $F_{\mathrm{c}}=2.58 \times 1.17^{(T-10) / 10}-2.86$ along a field gradient of $T$ (a: $R^{2}=0.8630$, RMSE $=0.2334$ ), and analysis of the contributions of dew amounts in $F_{X}$ with $F_{X}=-0.82 \times e^{10 \times d e w}+0.18\left(\mathrm{~b}: R^{2}=0.1008, \mathrm{RMSE}=0.4219\right)$ and $F_{X}=4.07 \times e^{-10 \times \mathrm{dew}}-6.38(\mathrm{c}$ : $R^{2}=0.5264$, RMSE $=0.7533$, where $F_{x}$ is defined as $\mathrm{CO}_{2}$ flux unexplained by the $Q_{10}$ model.

\section{Full Screen / Esc}

Printer-friendly Version

Interactive Discussion 